\title{
Post-Soviet diasporas in the age of the internet
}

\author{
Efim I. Pivovara, Vitaly F. Ershova, Maria V. Katagoshchinab \\ aRussian State University for the Humanities, \\ 6, Miusskaia Sq., Moscow, 125993, Russia, \\ rggu@rggu.ru, ershov_vf@mail.ru \\ bMoscow Pedagogical State University, \\ 1/1, Malaia Pirogovskaia Str., Moscow, 119991, Russia, \\ marya.katagoshina@yandex.ru
}

\begin{abstract}
This article examines the impact of recent developments in the diasporas of postSoviet nationalities during the early $21^{\text {st }}$ century. Its authors argue that new information technologies have a major impact on the creation of identities in diasporas, their interaction with the host countries and the historical homeland, as well as the social adaptation of migrants. Focusing on the evolution of expatriate communities in Russia and its "Near Abroad," they point out that these diasporas use the Internet to promote common historical, cultural and civilizational values. The article goes on to analyze the information policies of ethnic and cultural organizations, the integration of intellectual elites of post-Soviet diasporas into scientific and educational institutions, the impact of digital technologies on the business activity of diasporas, the daily life of migrant workers, as well as the participation of diasporas in international culture and public diplomacy. The authors conclude that modern means of communicating information have created a fundamentally new environment for migration flows and the creation of diasporas in the post-Soviet space and around the world. Today, this trend plays an important role in economic and cultural integration and social development of Eurasia.

Keywords: CIS, Eurasia, information technologies, financial technologies, public diplomacy, dialogue of cultures, Eurasian integration

For citation: Pivovar, Efim I., Ershov, Vitaly F., and Katagoshchina, Maria V. "Post-Soviet diasporas in the age of the internet." RUDN Journal of Russian History 20, no. 3 (August 2021): 437-447. https://doi.org/10.22363/2312-8674-2021-20-3-437-447
\end{abstract}

\section{Постсоветские диаспоры в век глобальной информационной цивилизации}

\author{
Е.И. Пивовара, В.Ф. Ершова, М.В. Катагощина \\ аРоссийский государственный гуманитарный университет, \\ 125993, Россия, Москва, Миусская пл., 6, \\ rggu@rggu.ru, ershov_vf@mail.ru \\ bМосковский государственный педагогический университет, \\ 119991, Россия, Москва, Малая Пироговская ул., 1/1, \\ marya.katagoshina@yandex.ru
}

\begin{abstract}
Аннотация: Статья посвящена влиянию тенденций глобального развития начала XXI века на мир диаспор народов постсоветских стран. Авторы выдвигают гипотезу о существенном влиянии информационных технологий на формирование идентичностей в диаспорах, характер взаимодействия диаспор с обществами принимающих стран и исторической родиной, на процессы социальной адаптации мигрантов. В работе отмечено широкое использование русскоговорящими диаспорами глобальной сети для продвижения общих историко-культурных и цивилизационных ценностей.
\end{abstract}


Основное внимание авторы уделяют эволюции диаспор народов стран СНГ в России и центров российского ближнего зарубежья в условиях информационного общества. Анализируется информационная политика этнокультурных организаций, интеграция интеллектуальных элит постсоветских диаспор в регионально-глобальные научные и образовательные системы, влияние цифровых технологий на деловую активность диаспор, повседневную жизнь трудовых мигрантов, участие диаспор в международном диалоге культур, мероприятиях публичной дипломатии. Авторы приходят к выводу о том, что современная информационная цивилизация создает принципиально новый социальнокультурный, правовой, финансовый контекст развития миграционных потоков и формирования диаспор на постсоветском пространстве и во всем мире. Во втором десятилетии XXI в. данная тенденция приобретает существенное значение как фактор международной экономической и культурной интеграции и социального развития Евразии.

Ключевые слова: СНГ, Евразия, информационные технологии, финансовые технологии, публичная дипломатия, диалог культур, евразийская интеграция

Для цитирования: Пивовар Е.И., Ершов В.Ф., Катагощина М.В. Постсоветские диаспоры в век глобальной информационной цивилизации // Вестник Российского университета дружбы народов. Серия: История России. 2021. Т. 20. № 3. С. 437-447. https://doi.org/10.22363/23128674-2021-20-3-437-447

\section{Introduction}

Scholars have been studying ethnic diasporas for several decades. The literature includes important theoretical works by V. Tishkova, G. Schaeffer, M. Esman, and others, ${ }^{1}$ as well as a large number of publications devoted to specific diasporas and their interaction with states and public institutions. The emergence in the late $20^{\text {th }}$ century in the Near Abroad of Russian-speaking diasporic communities and the development of multi-vector migrations in the post-Soviet space created many new topics for study as well as new theoretical approaches in the field. ${ }^{2}$

The ongoing evolution of the social image and institutions of post-Soviet diasporas, their growing economic and cultural importance, as well as changes and intensification of migration flows continue to pose new research challenges for scholars. ${ }^{3}$ Understanding the impact of diasporas on socio-economic and cultural developments in the post-Soviet space is becoming more relevant in the context of Eurasian integration in the $21^{\text {st }}$ century. ${ }^{4}$ Scholars at the Institute for Post-Soviet and Interregional Studies ${ }^{5}$ at the Russian State University for the Humanities (RUSH) have paid particular attention to this question.

This article's objective is to examine how the study of the diasporas of post-Soviet countries have developed under the impact of broader cultural changes in the $21^{\text {st }}$ century.

${ }^{1}$ V.A. Tishkov, "Istoricheskii fenomen diaspory [Historical phenomenon of the diaspora]," in Natsional'nye diaspory $v$ Rossii i za rubezhom $v$ XIX-XX vv. Sbornik statei [National diasporas in Russia and abroad in the XIX-XX centuries] eds. Yu.A. Poliakov, and G.Ya. Tarle (Moscow: The Institute of Russian History of RAS Publ., 2001), 9-44; G. Sheffer, Diaspora Politics: At Home Abroad (Cambridge: Cambridge University Press, 2003); M.J. Esman, Diasporas in the Contemporary World (Cambridge, MA: Polity Press, 2009) etc.

2 P. Kolstø, "Territorialising Diasporas: The case of Russians in Former Soviet Republics," Millennium: Journal of International Studies, 28, no 3 (December 1999), https://journals.sagepub.com/toc/mila/28/3; R. Brubaker, "Accidental Diasporas and External 'Homelands' in Central and Eastern Europe: Past and Present" Institute for Advanced Studies, Vienna, Political Science Series, no 71 (October 2000), https://aei.pitt.edu/32402/1/1208853582_pw_71.pdf; etc.

${ }^{3}$ M. Moseikina, "La experiencia de la adaptación social y la integración de los migrantes en Rusia a la luz de la crisis europea de migración," in Migración desde la ex URSS. La diáspora veinticinco años después (Mexico: Universidad Autónoma Metropolitana, Unidad Xochimilco, 2017), 187.

${ }^{4}$ E.I. Pivovar, Evraziiskii integratsionnyi proekt na postsovetskom prostranstve: predposylki, stanovleniie, razvitiie, (1991-2015 gg.) [Eurasian integration project in the post-Soviet space: prerequisites, formation, development, (1991-2015]. (St. Petersburg: Aleteia Publ., 2017).

5 A. Guschin, and A. Levchenkov, "Post-Soviet space in contemporary curricula and cooperation projects," Baltic Region, no. 3 (2010), 46-48; V.M. Shneider, "Fenomen ukrainskoi identichnosti. Istoricheskii ocherk [The phenomenon of Ukrainian identity. The phenomenon of Ukrainian identity. Historical feature article]," in Pivovar, E.I., ed. Institute of post-Soviet and interregional studies. Issue 1 (Moscow: RSUH Publ., 2018), 115-137 etc. 
The authors argue that intensifying informatization is leading to some changes in the world's diasporas, including those in the Eurasian space.

In this article "Eurasia" refers to the post-Soviet states. Meanwhile, the term "diaspora" is used for the communities of emigrants from the post-Soviet states living outside their historical homeland and united by a common identity. Their members express this identity by preserving their original citizenship as well as maintaining a strong interest in their personal ties with their homeland. They are characterized by a desire to preserve their identity as a group and some isolation from the society of the host country. The degree of such isolation is determined by the level of a particular diaspora's adaptation and assimilation to its host country. ${ }^{6}$

The article studies the various ways scholars have defined the term "diaspora". Meanwhile, it considers the development of dialogues between peoples in the context of the "complex and changing identity" of modern diasporas. ${ }^{7}$

\section{Some theoretical aspects of the study of post-Soviet diasporas}

Since the turn of the $21^{\text {st }}$ century scholars have increasingly considered the diaspora as a cross-border network structure comprising a variety of contacts and connections. ${ }^{8}$ Digitalization and the global dissemination of information have strengthened diaspora networks. On the one hand, this leads to blurred diaspora identities among youth who actively absorb globalized popular culture. But on the other, modern electronic resources allows both traditional and new diasporas to exchange more information. Beyond forming and consolidating their identities, this enables more effective mechanisms to provide legal and social support for migrants in host societies. Indeed, it has become possible to stay "in the diaspora outside the diaspora," as distance learning specialists, legal consultants, human rights defenders, financial experts, journalists, and others communicate with the inner world of diasporas throughout the world. This is particularly evident in the case of post-Soviet diasporas in the Eurasian space.

Today, the information space of the Russian abroad is actively developing as electronic media and corporate websites actively promote the exchange of information about the Russian diaspora. At the same time, its communities also work with each other, both thanks to private initiatives as well as such institutions as the International Council of Russian Compatriots and the Russkii Mir Foundation. This information space is linked to Internet resources in Russia, the European Union, Israel, the United States, China, and other countries, including Russian-language networks in the post-Soviet states.

It has been repeatedly noted that preserving its native language is an essential, but not necessary, component of maintaining a diaspora's identity. Thus, even third- and fourth-generation Russian emigrants who do not speak Russian, still identify themselves as being Russian. Nevertheless, the Russian language plays an important role in forming the diaspora's identity. The identities of many members of Russian-speaking communities abroad are complicated by ethnicity, language and ideas about the home country (region). For example, older migrants who left the USSR for the West still maintain a "Soviet" identity. This phenomenon finds its expression in their everyday traditions, interest in music, theater, and the media throughout Russia and its near abroad. Meanwhile, they preserve the memory of the Great Patriotic War, the flight of Yuri Gagarin, and other significant events in the history of the USSR. They also manifest their common identities

${ }^{6}$ Yu.P. Platonov, Etnicheskii faktor: Geopolitika i psikhologiia [Ethnic Factor: Geopolitics and Psychology] (St. Petersburg: Rech Publ., 2002), 406.

7 I.D. Loshkarev, "Evoliutsiia poniatiia 'diaspora' v sovremennoi politicheskoi nauke [Evolution of the concept of 'diaspora' in modern political science]," Etnosotsium i mezhnatsional'naia kul'tura, no. 4 (2017): 77-78.

${ }^{8}$ G. Sheffer, Diaspora politics: At home abroad, 167. 
on such occasions as the New Year holiday and Tatiana's Day, among other. Depending on their republic of origin, this Soviet diaspora sees its historical homeland both as Russia, Belarus, Ukraine, Kyrgyzstan and other republics as well as the Soviet Union as a whole. The same is also often true for members of more recent diasporas from Russia and other post-Soviet countries, as the Internet suggests. The Facebook page of Russian Youth of America proclaims,

By Russian youth, we do not mean exclusively immigrants from Russia... This group is for those who, while living in the United States, love Russia, remember its history and are proud of it! ${ }^{9}$

The combination of a historical memory and (as a rule) the Russian language forms a new identity, a "transnational community," 10 which can, with certain reservations, be called a Eurasian one. Russian, Belarusian, Kazakh and other national diasporas outside of post-Soviet Eurasia have adopted this identity to various degrees, and it is the basic bond for small Russian-speaking communities of emigrants from the CIS. This phenomenon manifests itself periodically, especially on common holidays, such as Victory Day, which marks the end of the Second World War. Thus, on May 9, 2021, citizens of Belarus, Ukraine, Kazakhstan, and a number of other countries joined the march of the "Immortal Regiment" held under the auspices of the Russian Consulate General in Shanghai.

The appearance of many documents and photographs of the war era on the Internet enabled thousands throughout the diaspora to feel that they helped preserve the memory of the Great Patriotic War's combatants. For migrants within the post-Soviet space, the feeling that they are part of a common Eurasian past helps to integrate themselves in their country of residence.

The informatization of the Russian diaspora, both as a single community and as a network of different ones, promotes the interaction of Russian compatriots throughout the world while also encouraging business, cultural, and educational cooperation.

\section{The diasporas of CIS countries and their institutions}

Spurred by the rise of nationalism during the twilight years of the Soviet Union, ethnic minorities in Russia, Kazakhstan and other constituent republics began to set up cultural and humanitarian organizations around 1990, a process that been boosted by modernization among the post-Soviet states and increased Eurasian integration in the early $21^{\text {st }}$ century.

The Internet has provided many new opportunities for members of the diaspora to express themselves in traditional and social media, as well as electronic scholarly publications. At the same time, modern electronic communications are mostly used by diasporas with strong institutions, more highly educated people, as well as representatives in government, business, the scientific community, the arts, and the media. Such diasporas endeavor both to achieve a high level integration in the host country while also preserving their national culture.

The Azerbaijani diaspora's "Ojag" society headed by, among other the philologist, Professor T.V. Melikli, is striking example of an organization that involves members of the academic and cultural intelligentsia. The Azerbaijani diaspora in Russia is one of the largest; according to the 2010 census, its numbers over 600,000 Azeris. For many years its leading leading institutions have been the All-Russian Azerbaijan Congress and the Azerbaijani Youth Association of Russia (AMOR), and there are various other lite-

\footnotetext{
${ }^{9}$ Russkaia molodezh' Ameriki. Obshchedostupnaia gruppa [Russian youth of America. Public group], https://www.facebook.com/groups/rusyouthusa/

${ }^{10}$ V.A. Tishkov, Rekviem po etnosu: Issledovaniia po sotsial'no-kul'turnoi antropologii [Requiem for Ethnos: Studies in Socio-Cultural Anthropology] (Moscow: Nauka Publ., 2003), 464.
} 
rary, historical and cultural societies. ${ }^{11}$ These organizations actively promote a positive image of their homeland's traditional culture and the achievements of modern Azerbaijan through their official websites and social media. Meanwhile, AMOR's website provides extensive coverage of news about Russia, Azerbaijan and the Azeri diaspora in Russian, Azerbaijani and English, as well as of its own initiatives, such as the AMOR School of Young Scientists. ${ }^{12}$

The Belarusian, Armenian, Georgian, and Ukrainian diasporas have similar social and cultural organizations in Eurasia. Thus, Belarusian publishers, institutions, museums, clubs, and radio stations carry out various cultural activities to support their national traditions in Russia and through the Internet. ${ }^{13}$ Established in 2018, one of the main goals of the Association of Armenians of Russia is to support educational projects and a dialogue of cultures through its "Portal to the Armenian World." the Federal Georgian National-Cultural Autonomy in Russia provides a wide range of materials about the history of the Georgian Diaspora in Russia, its institutions, prominent individuals and public initiatives.

Despite its large size (about 647,000 people according to 2010 data), the Kazakh community in Russia uses the Internet less actively to promote the activities of its cultural and social organizations, and only a few of them have professionally designed sites and pages on social media. Meanwhile, there are almost no independent websites of the Uzbek diaspora's institutions, although the Moscow House of Nationalities, the House of Friendship of Peoples of the Samara Region and some other Russian public organizations keep databases of relevant information. The low educational levels and poor language skills of Central Asian migrants in Russia considerably hampers their integration into Russian and Eurasian society and culture.

Details about ethno-cultural associations in Kazakhstan are posted on the website of the Assembly of Peoples of Kazakhstan and on social media, while the joint portal, "Russian Compatriots in the Republic of Uzbekistan," provides some information about Russian, Bashkir and Tatar cultural centers there. As for Azerbaijan, expatriate organizations, including the Russian Community of Azerbaijan, the Association of Russian Youth of Azerbaijan (ARMA), the Center of Russian Culture, etc., use the Internet more actively.

\section{Post-Soviet diasporas in regional and international intellectual dialogs}

One of the new century's most important social developments is the rise of organizations of scientists and other academics of the diasporas. These include communities of Russian-speaking scientists and students in the Near and Far abroad. Some function as transnational networks that bring migrants from the USSR and post-Soviet countries together, including the Russian-speaking Academic Science Association (RASA), Association of Russian-Speaking Science \& Technology Professionals (SciTech), and Association of RussianSpeaking Bio-Scientists (BIORUS), etc. Others have been established for scientist in diasporas in a particular country: Russian American Medical Association (RAMA), the Society of Russian-speaking Scientists and Innovative Entrepreneurs of Finland Science, etc. The Adyghe (Circassian) International Academy of Sciences (AMAN) brings together Rus-

${ }^{11}$ U.M. Mehdieva, “Azerbaidzhanskaia diaspora v Rossii: istoricheskii opyt i perspektivy [Azerbaijani Diaspora in Russia: Historical Experience and Prospects]," Klio, no. 8 (2014): 103-106.

12 Shkola molodogo uchenogo AMOR [School of a young scientist AMOR], AMOR website, http://amor.az/ 12-мая-прошла-заключительная-лекция-шко/

${ }^{13}$ D.A. Taras, "Organizatsii belorusskoi diaspori v Rossii v kontse XX - nachale XXI veka [Organizations of the Belarusian diaspora in Russia in the late XX - early XXI century]," in Aktual'nie problemy mezhdunarodnykh otnosheniy i global'nogo razvitiia: sbornik nauchnykh statei [Actual problems of international relations and global development: a collection of scientific articles]. Issue 6, (Minsk: BSU Publ., 2018), 165-182.

14 'Sostoialas' prezentatsiia obshchestvennoi organizatsii 'Ob"edinenie armian Rossii' [Presentation of the public organization 'Union of Armenians of Russia']," REGNUM. Yerevan, June 9, 2018, https://regnum.ru/news/society/2429479.html 
sian scientists and representatives of the diasporas of the Adyghe peoples of the European Union, the United States, the Middle East, and other regions of the world.

The intellectual elites of post-Soviet diasporas often organize themselves in associations of university graduates in 68 countries. In 2015, the Global Alumni Alliance was founded in Moscow to provide mutual social and professional support to its members, as well as to develop an international intellectual dialogue. One of its endeavors is to organize meetings of Russian university graduates in the CIS, Europe, and Africa. In 2020, the alliance's priority was to create an International Media Resource Center to conduct its public diplomacy and to develop contacts with graduates of Soviet and Russian universities.

These post-Soviet academic diasporas of the $21^{\text {st }}$ century take an active interest in science and higher education in the historical homeland. ${ }^{15}$ More than $80 \%$ of the representatives of the academic diaspora in Russia and the CIS countries maintain links with their colleagues at home as well as participating in joint research and scientific publications. ${ }^{16}$ The governments of Russia, Belarus and other CIS countries also cooperate with representatives of their scientific communities abroad. By the same token, Russianspeaking scientists living abroad organize and participate in international research projects, scientific forums, and educational programs. Online systems of communication and scientific publications are evidence of their work.

Post-Soviet diasporas also organize events dedicated to individual disciplines. For example, the St. Petersburg Association of Belarusian language experts has been organizing "St. Petersburg and Belarusian Culture" forums since 1991, while the Association of Scientists-Historians of Uzbekistan and Russia is planning to develop cooperation with colleagues in other Eurasian countries.

Intellectual dialogue in the post-Soviet space is developing under interstate programs of scientific cooperation between the CIS and the EAEU involving the Russian Near Abroad and scientists from post-Soviet countries working in Russia has promoted intellectual dialog among them. The Council for Cooperation in Basic Research of the CIS Member States, the Forum of Scientists-Compatriots of the CIS, and the Eurasian Universities Association play a leading role, while international programs of interuniversity cooperation, as well as university networks of the CIS, the EAEU and the SCO also make a significant contribution to the development of modern intellectual communications as a mechanism for Eurasian integration. ${ }^{17}$

Due to the difficult geopolitical situation of the late 2010s, Russia's interaction with Russian-speaking communities beyond the CIS diminished. As a result, cooperation between Eurasian scientists has become all the more important.

\section{Diasporas and financial systems in Eurasia}

Modern information technologies in the Eurasian space can help integrate postSoviet countries into the regional and global trade, economic, investment, industrial and technological establishments. ${ }^{18}$ Therefore, modernizing the financial systems of the CIS

15 A.G. Allahverdjan, and N.S. Agamova, "Rossiiskaia nauchnaia diaspora i mobil'nost' uchenykh migrantov v SSHA (konets KHKH - nachalo XXI veka) [Russian scientific diaspora and the scientists-migrants' mobility to the USA (late $20^{\text {th }}$ - early $21^{\text {st }}$ centuries)]," Sotsiologiia nauki i tekhnologii, 3, no. 3 (2012): $43-53$.

${ }^{16}$ V.A. Malakhov, and A.V. Smirnova, "Vzgliad iz-za rubezha: problemy i perspektivy vzaimodeistviia s russkoiazychnoi nauchnoi diasporoi, [A look from abroad: problems and prospects of interaction with the Russian-speaking scientific diaspora]." Upravlenie naukoi i naukometriia 14, no. 4 (2019): 584-611.

17 E.I. Pivovar, The World of Russian emigres in the late XX-early XXI centuries (St. Petersburg: Aleteia Publ., 2021), 107-142.

${ }^{18}$ M.A. Eskindarov, "Problemy integratsii finansovykh rynkov stran Edinogo ekonomicheskogo prostranstva [Problems of financial markets integration of the countries of the Common Economic Space]," Finansy: teoriia i praktika, no. 1 (2014): 8-19. 
and the EAEU countries is priority for the economic and socio-cultural development of the Eurasian region. ${ }^{19}$

Much attention is being paid to a currency union and a single payment market in the EAEU, and these are being considered in implementing the strategy for the development of the Russian national payment system. ${ }^{20}$

The study of financial and economic relations between the post-Soviet countries as one of the key aspects of Eurasian integration is one of the activities of The Institute for Post-Soviet and Interregional Studies. ${ }^{21}$ Research shows that international cooperation between banking institutions together with introducing modern financial technologies and services in the post-Soviet space is important to develop businesses of diasporas in their host countries. By the same token, they play a critical role in the daily lives of migrant workers, who rely on electronic payment systems to send their earnings to their families back home. This relationship between migration and financial flows has encouraged leading banks in Russia, Kazakhstan, and Armenia to set up branches in other CIS countries, as well as to improve their cooperation with major international financial institutions operating in Eurasia.

The business elites of CIS diasporas work well with the banking systems in their countries of residence, while also supporting charitable and humanitarian projects in their historical homeland. For example, one of the leading investment bankers in Russia, R. Vardanian, is a co-founder of the IDeA (Initiatives for Development of Armenia) charitable foundation, and contributed to the opening of the UWC Dilijan College in Armenia, etc. ${ }^{22}$

As leading players in facilitating financial flows in the post-Soviet space, Sberbank, Alfa-Bank, VTB, Raffeisenbank, Roseximbank (Russia), BTA Bank, Kazkommertsbank (Kazakhstan), the International Bank of Azerbaijan (IBA) and a number of other financial institutions are actively developing their institutional and technological infrastructure to expand their commercial and private banking. Meanwhile, Eurasia's leading banks also have representative offices in Europe, the United States, and China, which allows them to serve clients among post-Soviet diasporas beyond Eurasia.

The interaction of financial institutions in the Eurasian space boosts its economy, whose growth in the modern age would be impossible without financial information technologies. By the same token, the involvement of diasporas in business in the region is also growing. Thus, on 8 December 2020 the Business Club of the Trade Representative of the Republic of Azerbaijan hosted a Forum on "Azerbaijan-Russia: Economic Diplomacy and Partnership Strategy" in Moscow, which was attended by statesmen, business-

${ }^{19}$ V.F. Ershov, "Finansovaia sistema Rossii v kontekste modernizatsii sotsial'nogo prostranstva SNG i Blizhnego zarubezh'ia [The financial system of Russia in the context of modernization of the social space of the CIS and the Near Abroad]," Perspektivy nauki, no. 4 (2015): 158-162.

20 A. Obaeva, and V. Balchinova, "Evraziiskii ekonomicheskii soiuz: perspektivy sotrudnichestva v platezhnoi sfere [Eurasian Economic Union: prospects for cooperation in the payment sphere]," Mezhdunarodnye bankovskie operatsii, no. 2 (2018): 6-12.

${ }^{21}$ E.Ya. Vittenberg, and E.I. Pivovar, "Sotrudnichestvo rossiiskogo i ukrainskogo biznesa v sfere investitsii (1991-2013) [Cooperation of Russian and Ukrainian business in the sphere of investment (1991-2013)]," in Pivovar, E.I., ed. Institute of post-Soviet and interregional studies. Issue 1 (Moscow: RSUH Publ., 2018), 9-72; E.Ya. Vittenberg, "Cooperation of Russian and Kazakhstan business: achievements and problems," in Pivovar, E.I., ed. Institute of post-Soviet and interregional studies. Issue 2, (Moscow: RSUH, 2019), 104-168; V.F. Ershov, "Russia and Kazakhstan: Interbank Interaction within the Eurasian Union," Pivovar, E.I., ed. Institute of post-Soviet and interregional studies. Issue 2 (Moscow: RSUH Publ., 2019), 169-105; E.Ya. Vittenberg, and E.I. Pivovar, "Rossiisko-azerbaidzhanskoe sotrudnichestvo v sfere biznesa: dostizheniia, problemy, perspektivy," in Pivovar, E.I., ed. Institute of post-Soviet and interregional studies. Issue 3 (Moscow: RSUH, 2020), 9-102.

22 "Publichnaia lektsiia R.K. Vardaniana 'Migratsiia v budushchee' [Public lecture bi R.K. Vardanian 'Migration to the Future']," Lomonosov Moscow State University. History Departent website, September 17, 2019, http://www.hist.msu.ru/partnerships/news-cooperation/54246/ 
men and diplomats of both countries, including leading representatives of the business community of the Azeri diaspora.

In general, the development of banking technologies encourages international cooperation in business education and science, as well as promoting a dialogue between entrepreneurs, experts, and youth in Eurasia, which ultimately benefits the post-Soviet diasporas there.

\section{Diasporas and culture}

Diasporas often best express their identity in their host countries through art and culture. ${ }^{23}$ Under the auspices of the Council for Cultural Cooperation of the CIS Member States, as well as governments and leading cultural institutions of the post-Soviet countries, their expatriates organized a wide range of events in the $2010,{ }^{24}$ including the "CIS Historical and Cultural Heritage Year" in 2011, the Year of Culture (2018) and a number of other initiatives that were widely covered in the international press.

Creative elites, business circles and many others in diaspora communities have been keen to participate in such initiatives as the Russia-Kazakhstan $21^{\text {st }}$ Century Art Festival (held since 2013), nomadic culture festivals in Kazakhstan and Azerbaijan, as well as days of national culture, including those at the regional level, such as the Day of Belarusian Culture in Moscow (2017) and the Days of Culture of Turkmenistan in Kazan (2019). Members of the diasporas have also participated in such events as the exhibition of works by Russian artists of Azerbaijan (Baku, 2004), the "Georgian Artists" exhibition (Moscow, 2017) and in many other projects, which all create a positive, tolerant space for a cultural dialogue among the peoples of Eurasia. ${ }^{25}$

Meanwhile, the regular seasonal cultural and artistic festivals that are mainly organized by the diasporas have become true celebrations of friendship and tolerance, including the Moldovan spring festival "Mărțișor," "The Autumn gifts of Azerbaijan" in Moscow, the "We live in one family" summer festival of the Azerbaijani ethno-cultural association "Vatan" in Kazakhstan, etc.

The Internet, which facilities the promotion of concerts fairs, exhibitions, etc., is critical for the cultural life of post-Soviet diasporas in Eurasia. For example, the Moscow blogger Fatima Arifjanova created the project "Untold Stories of Pomegranate" dedicated to Uzbekistan on Facebook, which proved to be he most important cultural event in the life of Moscow's Uzbek community. In the countries of the CIS, representatives of Rossotrudnichestvo (the Federal Agency for the Commonwealth of Independent States Affairs, Compatriots Living Abroad, and International Humanitarian Cooperation) actively exploit the Internet by posting educational materials, information about events in Russia, the Near Abroad and beyond on their websites, in the media, and social networking websites.

Virtual museums, exhibitions, and concerts that cater to the cultural interests of the diasporas also provide many opportunities. The Russian Museum and the Tretyakov Gallery took the first steps in this direction by presenting digital exhibitions in the Centers of Russian Science and Culture Abroad, including in the CIS countries. In 2010, youth and children around the world were invited to create a Virtual Museum of Space Exploration.

${ }^{23}$ R.S. Tabasaranski, "Diaspora kak prostranstvo dialoga kul'tur [Diaspora as a space for the dialogue of cultures]," in Dialog kul'tur i vyzovy sovremennoi epokhi: Materialy Bakinskogo foruma, posviashchennogo pamiati Geidara Alieva [Dialogue of cultures and challenges of the modern era: Materials of the Baku Forum dedicated to the memory of Heydar Aliyev] (Moscow: Kanon+ Publ., 2019), 132-141.

${ }^{24}$ Fokin, Bogoliubova and Nikolaeva 2017

25 Vesnina T.L., and T.N. Mikutskaia, eds. Iskusstvo za tolerantnost'. Khudozhniki blizhnego zarubezh'ia v kollektsii Tomskogo oblastnogo khudozhestvennogo muzeia: katalog [Catalogue 'The Art for Tolerance. The Artists of Post-Soviet Region in Collection of the Tomsk Region Art Museum'] (Tomsk: Tomskii vestnik Publ., 2010). 
Meanwhile, a virtual museum of private art collections of Russia is being developed, ${ }^{26}$ and a Iu. Verbitskaia's collection of contemporary fine arts of Tajikistan as well as Tahir F. Tairov's collection of traditional Central Asian textiles may also become exhibits.

Presenting works of art as well as historical and cultural monuments in cyberspace provides important new opportunities for diasporas to preserve their cultural identity; it has now become possible to provide free access to music, cinema, traditional and new art of the peoples of Eurasia. At the same time, the Internet as a platform for cultural dialogue is still in its formative stage. Its future will depend on the participation of government and public institutions.

\section{Conclusions}

Increasing globalization in the $21^{\text {st }}$ century is having growing impact on the diasporas, both on their internal lives as well as on information, financial, economic and cultural interaction between the post-Soviet states, Thus, global information systems ensure the flow of public and private communications within and outside diasporas, financial flows, the organization of online events, communication with relatives and potential employers, and the promotion of images of the historical homeland while also helping to accelerate the adaptation and integration of migrants in their host countries.

Legal reference portals, electronic documentation, signatures, electronic translators, and bank cards create fundamentally different conditions for migration and the development of diaspora institutions in the post-Soviet space. At the same time, how many of these new opportunities are used by diasporas largely determines their role in the economy and culture, while also directly affecting their host countries.

The contribution of the diasporas of the peoples of the post-Soviet countries to developing Eurasia's information in the early $21^{\text {st }}$ century is determined by the activity of scientists, cultural and business figures interested in improving international relations, forming new institutions and other forms of cooperation in their field, as well as participating in the public life of the countries of residence.

The modern post-Soviet ethnic diasporas and their new communities of scientists, university graduates, etc. play a role in developing information communications and the digital economy, thereby promoting Eurasian integration. The future prospects for information technologies in the post-Soviet space is based on creative interaction between the government institutions of the CIS and the EAEU and the civil societies of the Eurasian countries, of which the post-Soviet diasporas are an integral part.

The growing influence of informatization processes on the society, economy, and everyday culture of Eurasian countries necessitates setting new tasks for scholars who study diasporas in the post-Soviet space. It seems particularly important to continue examining the impact of information technologies on the formation of migration flows in Eurasia and on the assimilation of migrants in their host countries. It would also be useful to carry out a comparative analysis of the nature and level of involvement of the diasporas of the post-Soviet countries in the modern information community in Eurasia and elsewhere. And one worthwhile task of applied research would be to build databases of diasporas and various demographic and professional groups within a particular diaspora.

Submitted / Поступила в редакцию: 15.05.2021

${ }^{26}$ E.V. Nikolaeva, "Kontseptsiia virtual'nogo muzeia 'Chastnye khudozhestvennye kollektsii Rossii' [The concept of the virtual museum 'Private art collections of Russia']," Vestnik Sankt-Peterburgskogo gosudarstvennogo universiteta kul'tury i iskusstv, no. 2 (2017): 112-115. 


\section{References}

Allahverdzhan, A.G., and Agamova, N.S. "Rossiiskaia nauchnaia diaspora i mobil'nost' uchenykh migrantov v SSHA (konets XX - nachalo XXI veka).” Sotsiologiia nauki i tekhnologii 3, no. 3 (2012): 43-53 (in Russian).

Brubaker, R. "Accidental Diasporas and External 'Homelands' in Central and Eastern Europe: Past and Present." Institute for Advanced Studies, Vienna. Political Science Series, no. 71 (October 2000), https://aei.pitt.edu/32402/1/1208853582_pw_71.pdf

Ershov, V.F. "Finansovaia sistema Rossii v kontekste modernizatsii sotsial'nogo prostranstva SNG i Blizhnego zarubezh'ia." Perspektivy nauki, no. 4 (2015): 158-162 (in Russian).

Ershov, V.F. "Russia and Kazakhstan: Interbank Interaction within the Eurasian Union." In Pivovar, E.I., ed. Institute of post-Soviet and interregional studies. Issue 2, 169-205. Moscow: RSUH Publ., 2019 (in Russian).

Eskindarov, M.A. "Problemy integratsii finansovykh rynkov stran Edinogo ekonomicheskogo prostranstva." Finansy: teoriia i praktika, no. 1 (2014): 8-19 (in Russian).

Esman, M.J. Diasporas in the Contemporary World. Cambridge, MA: Polity Press, 2009.

Guschin, A., and Levchenkov, A. "Post-Soviet Space in Contemporary Curricula and Cooperation Projects." Baltic Region, no. 3, (2010): 46-48.

Kolstø, Pål. "Territorialising Diasporas: The case of Russians in Former Soviet Republics." Millennium: Journal of International Studies 28, no. 3 (December 1999), https:/journals.sagepub.com/toc/mila/28/3

Loshkarev, I.D. "Evoliutsiia poniatiia 'diaspora' v sovremennoi politicheskoi nauke." Etnosotsium $i$ mezhnatsional'naia kul'tura, no. 4 (2017): 77-78 (in Russian).

Malakhov, V.A., and Smirnova, A.V. "Vzgliad iz-za rubezha: problemy i perspektivy vzaimodeistviia s russkoiazichnoi nauchnoi diasporoi." Upravlenie naukoi i naukometriia 14, no. 4 (2019): 584-611 (in Russian).

Mekhdieva, U.M. "Azerbaidzhanskaia diaspora v Rossii: istoricheskii opyt i perspektivy.” Klio, no 8 (2014): 103-106.

Moseikina, M. "La experiencia de la adaptación social y la integración de los migrantes en Rusia a la luz de la crisis europea de migración." In Migración desde la ex URSS. La diáspora veiniticinco años después, 161-186. Mexico: Universidad Autónoma Metropolitana, Unidad Xochimilco, 2017 (in Spanish).

Nikolaeva, E.V. "Kontseptsiia virtual'nogo muzeia 'Chastnye khudozhestvennye kollektsii Rossii'." Vestnik Sankt-Peterburgskogo gosudarstvennogo universiteta kul'tury i iskusstv, no. 2 (2017): 112-115 (in Russian).

Obaeva, A., and Balchinova, V. "Evraziiskii ekonomicheskii soiuz: perspektivy sotrudnichestva v platezhnoi sfere." Mezhdunarodnye bankovskie operatsii, no. 2 (2018): 6-12 (in Russian).

Pivovar, E.I. Evraziiskii integratsionnyi proekt na postsovetskom prostranstve: predposylki, stanovlenie, razvitie (1991-2015 gg.). St. Petersburg: Aleteia Publ., 2017 (in Russian).

Pivovar, E.I. The World of Russian Emigres in the Late XX - early XXI Centuries. St. Petersburg: Aleteia Publ., 2021.

Platonov, Iu.P. Etnicheskii faktor: Geopolitika i psikhologiia. St. Petersburg: Rech Publ., 2002 (in Russian).

Sheffer, G. Diaspora politics: At Home Abroad. Cambridge: Cambridge Univ. Press, 2003.

Shneider, V.M. "Fenomen ukrainskoi identichnosti. Istoricheskii ocherk." In Pivovar, E.I., ed. Institute of post-Soviet and interregional studies, Issue 1, 115-137. Moscow: RSUH Publ., 2018 (in Russian).

Tabasaranskii, R.S. "Diaspora kak prostranstvo dialoga kul'tur." In Gezalov, A.A., and MamedZade, I.R. eds. Dialog kul'tur i vyzovy sovremennoi epokhi: Materialy Bakinskogo foruma, posviashchennogo pamiati Geidara Alieva, 132-141. Moscow: Kanon+ Publ., 2019 (in Russian).

Taras, D.A. "Organizatsii belorusskoi diaspory v Rossii v kontse XX - nachale XXI veka." In Aktual'nye problemy mezhdunarodnykh otnosheny i global'nogo razvitiia: sbornik nauchnykh statei. Issue 6, 165-182. Minsk: BSU Publ., 2018 (in Russian).

Tishkov, V.A. "Istoricheskii fenomen diaspory." In Poliakov, Yu.A., and Tarle G.Ya., eds. Natsional'nye diaspory v Rossii $i$ za rubezhom $v$ XIX-XX vv. Sbornik statei, 9-44. Moscow: The Institute of Russian History of RAS Publ., 2001, (in Russian).

Tishkov,V.A. Rekviem po etnosu: Issledovaniia po sotsial'no-kul'turnoi antropologii. Moscow: Nauka Publ., 2003 (in Russian).

Vesnina, T.L., and Mikutskaia, T.N., eds. Iskusstvo za tolerantnost'. Khudozhniki blizhnego zarubezh'ia $v$ kollektsii Tomskogo oblastnogo khudozhestvennogo muzeia: katalog. Tomsk: Tomskii vestnik Publ., 2010 (in Russian). 
Vittenberg, E.Ya. "Cooperation of Russian and Kazakhstan business: achievements and problems." In Pivovar, E.I., ed. Institute of post-Soviet and interregional studies. Issue 2, 104-168. Moscow: RSUH Publ., 2019 (in Russian).

Vittenberg, E.Ya., and Pivovar, E.I. "Rossiisko-azerbaidzhanskoe sotrudnichestvo v sfere biznesa: dostizheniia, problemy, perspektivy." In Pivovar, E.I., ed. Institute of post-Soviet and interregional studies, Issue 3, 9-102. Moscow: RSUH Publ., 2020 (in Russian).

Vittenberg, E.Ya., and Pivovar, E.I. "Sotrudnichestvo rossiyskogo i ukrainskogo biznesa v sfere investitsii (1991-2013).” In Pivovar, E.I., ed. Institute of post-Soviet and interregional studies. Issue 1, 9-72. Moscow: RSUH Publ., 2018 (in Russian).

\section{Информация об авторах / Information about the authors}

Пивовар Ефим Иосифович, доктор исторических наук, профессор, член-корреспондент РАН, президент Российского государственного гуманитарного университета, директор Института постсоветских и межрегиональных исследований РГГУ, заведующий кафедрой истории стран ближнего зарубежья МГУ имени М.В. Ломоносова.

Ершов Виталий Федорович, доктор исторических наук, профессор, главный научный сотрудник кафедры стран постсоветского зарубежья Института постсоветских и межрегиональных исследований РГГУ.

Катагощина Мария Всеволодовна, кандидат исторических наук, ведущий специалист Центра изучения исторической памяти и гражданской идентичности Московского государственного педагогического университета.
Efim I. Pivovar, Doktor Istoricheskikh Nauk [Dr. habil. hist.], Professor, Corresponding Member of the Russian Academy of Sciences, Director of the Institute of Post-Soviet and Interregional Studies of the Russian State University for the Humanities, Head of the Department of History of the Near Abroad, Lomonosov Moscow State University.

Vitaly F. Ershov, Doktor Istoricheskikh Nauk [Dr. habil. hist.], Professor, Chief Researcher of the Department of Post-Soviet Abroad Countries, Institute of Post-Soviet and Interregional Studies of Russian State University for the Humanities.

Maria V. Katagoshchina, Candidat Istoricheskikh Nauk [PhD in History], Leading Specialist of the Center for the Study of Historical Memory and Citizen Identity, Moscow State Pedagogical University. 